\title{
Colchicine Induced Hypoglycemia: A Case Report
}

\author{
Ahmad Nafi ${ }^{1}$, Momtaz Begum², Nasser Hamid ${ }^{3}$, Mehedi Hasan ${ }^{4}$ \\ ${ }^{1}$ Indoor Medical Officer (IMO), Department of Medicine, Jalalabad Ragib Rabeya Medical College Hospital, \\ Sylhet, Bangladesh; ${ }^{2}$ Associate Professor, Department of Medicine, Jalalabad Ragib Rabeya Medical College \\ Hospital, Sylhet, Bangladesh; ${ }^{3}$ Assistant Registrar, Department of Medicine, Jalalabad Ragib Rabeya \\ Medical College Hospital, Sylhet, Bangladesh; ${ }^{4}$ Indoor Medical Officer (IMO), Department of \\ Medicine, Jalalabad Ragib Rabeya Medical College Hospital, Sylhet, Bangladesh
}

[Received: 30 October 2018; Accepted: 2 November 2018; Published: 1 January 2019]

\begin{abstract}
Colchicine is a classical alkaloid drug extracted from plants of the genus Colchicum. Colchicine is very rarely seen as a cause of hypoglycemia. Here we reported a 65 years old female that presented with erythema nodusum, and developed hypoglycemia after being treated with Colchicine. [Journal of National Institute of Neurosciences Bangladesh, 2019;5(1): 87-89]
\end{abstract}

Keywords: Glucose stimulated insulin secretion(GSIS); colchicine; hypoglycemia; microtubules

Correspondence: Dr. Ahmad Nafi, Indoor Medical Officer, Department of Medicine, Jalalabad Ragib Rabeya Medical College and Hospital, Pathantula, Sylhet-3100, Bangladesh; Email: drnafi1990@gmail.com; Cell no.: +8801717594997

Conflict of interest: There is no conflict of interest relevant to this paper to disclose.

Contribution to authors: Ahmad Nafi and Nasser Hamid have contributed from the diagnosis, management and monitoring of the patient. Manuscript writing was performed by Ahmad Nafi and Mehedi Hasan. Associate Professor Momtaz Begum was involved in plan of investigations, preparation and revision of this manuscript.

How to cite this article: Nafi A, Begum M, Hamid N, Hasan M. Cholchicine Induced Hypoglycemia : A Case Report. J Natl InstNeurosci Bangladesh, 2019;5(1): 87-89

Copyright: (C2019. Nafi et al. Published by Journal of National Institute of Neurosciences Bangladesh. This article is published under the Creative Commons CC BY-NC License (https://creativecommons.org/licenses/by-nc/4.0/). This license permits use, distribution and reproduction in any medium, provided the original work is properly cited, and is not used for commercial purposes.

\section{Introduction}

Colchicine is an alkaloid extracted from plants of the genus Colchicum (Colchicum autumnale). The therapeutic use of colchicine has been well documented in gout and familial Mediterranean fever (FMF); It has also been used in other diseases including Bechet's disease, pericarditis, coronary artery disease, and other inflammatory and fibrotic conditions ${ }^{1}$. Colchicine has also been used as a second line agent for treatment of erythema nodusum ${ }^{2}$.

Colchicine inhibitsmicrotubule polymerization by binding to tubulin, one of the main constituents of microtubules. Availability of tubulin is essential for mitosis, so colchicine effectively functions as a "mitotic poison" or spindle poison. Apart from inhibiting mitosis (a process heavily dependent on cytoskeletal changes), it also inhibits neutrophil motility and activity, leading to a net anti-inflammatory effect. Colchicine has a narrow therapeutic window; the most common adverse reactions are abdominal pain, diarrhea, nausea, and vomiting ${ }^{3}$. At therapeutic doses of colchicine, blood dyscariasis have been reported including myelosuppression, leukopenia, granulocytopenia, thrombocytopenia, pancytopenia, and aplastic anemia ${ }^{4}$. Colchicine has also been listed as a drug which can cause hypoglycemia under special circumstances like malnutrition, infection, renal insufficiency ${ }^{5}$. Here we reported a case of Colchicine induced hypoglycemia in a 65 years old female patient presented with erythema nodusum.

\section{Case Presentation}

A 65 yearsold ex-smoker previously non-diabetic, normotensive female, hailing from Sylhet was admitted into the department of medicine of Jalalabad Ragib Rabeya Medical College Hospital, Sylhet with the complaints of multiple rounded painful swelling over both lower limbs for seven days. She was also suffering from Chronic Obstructive Pulmonary disease and took doxofylline and montelukast on a regular basis. On examination, patient was toxic, overweight, non-anemic, and non-icteric. Several reddish nodular swellings were present over both lower limbs. Her 
respiratory rate was 16 breaths/minute, pulse rate was 80beats/min and blood pressure was 120/80 mm of $\mathrm{Hg}$. Examination of respiratory system revealed vesicular breath sound with prolonged expiration and rhonchi. Other systemic examinations had revealed normal.The capillary blood glucose level of the patient was measured by glucometer and it was $10 \mathrm{mmol} / \mathrm{L}$, so diabetic chart was maintained. The patient was diagnosed as a case of COPD and Erythema Nodusum and suspected Type II DM and was treated with oral NSAID's and i/v co-amoxiclav. Initial investigations revealed high ESR ( $85 \mathrm{~mm}$ in 1st hour); however, ECG, serum creatinine, serum electrolytes and serum TSH were within normal limit.After discussing with the Dermatology department for her skin lesions it has been reached an additional diagnosis of post streptococcal erythema nodusum. According to the suggestion of the dermatology department $0.6 \mathrm{mg}$ Colchicine was added to the treatment on a twice daily dose along with Calamine lotion, Betamethasone ointment. The next morning patient woke up and became restless and unable to speak and there was profuse sweating. The blood pressure (BP) was $140 / 80 \mathrm{~mm}$ of $\mathrm{Hg}$; pulse rate was 96 beats/min; respiratory rate was 20 breaths/min. Neurological examinations revealed no focal neurologicaldeficit; deep reflexes were normal;plantar reflex was bilaterally flexed. ECG showed sinus tachycardia, however, capillary blood revealed hypoglycemia $(2.4 \mathrm{mmol} / \mathrm{L})$, although the previous whole day diet was normal. Capillary blood glucose was immediately re-checked with a different glucometer, which also revealed hypoglycemia $(2.3 \mathrm{mmol} / \mathrm{L})$. The patient was immediately managed with $100 \mathrm{ml}$ of $25 \%$ Dextrose intravenous solution, and gradually became normal. The capillary blood glucose was rechecked, and it was $15 \mathrm{mmol} \mathrm{L}$. The patient was given maintenance dose of $1000 \mathrm{ml}$ of $10 \%$ Dextrose solution and the blood glucose level was monitored hourly. Colchicine was immediately stopped and patient was closely monitored for 2 days. Meanwhile CT scan of whole abdomen and serum lipase level were checked to exclude pancreatic pathology and was revealed no abnormality. The C-peptide level was checked, which was slightly higher than normal range, which could be due to insulin resistance state like obesity. Other causes of spontaneous hypoglycemia were excluded. After monitoring diabetic chart for 2 days; the patient's capillary blood glucose level remained constantly in the range of 10 to $13 \mathrm{mmol} / \mathrm{L}$; therefore, the patient was advised to do OGTT which was within the diabetic range; thus the patient was also diagnosed as a case of type-2 diabetes mellitus. During discharge, the patient had been diagnosed as a case of type-2 DM with COPD as well as post-streptococcal erythema nodosum and colchicine induced hypoglycemia which was resolved. The treatment with metformin $500 \mathrm{mg}$ was started on a twice daily dose. During the follow-up visit it had been found normal random plasma glucose and erythema nodosum was completely resolved. Haemoglobin was normal $(11.7 \mathrm{gm} / \mathrm{dL})$; ESR was high $(85 \mathrm{~mm}$ in $1 \mathrm{st}$ hour), TC of WBC was normal $(9.5 \mathrm{~K} / \mu \mathrm{L})$; Platelets was normal $(320 \mathrm{~K} / \mu \mathrm{L})$. Serum Creatinine was normal $(0.96 \mathrm{mg} / \mathrm{dL})$. Serum TSH was within normal limit (1.99 $\mu \mathrm{IU} / \mathrm{ml})$. Lipase was normal (181 U/L). C-peptide was higher than normal value $(14.52 \mathrm{ng} / \mathrm{ml})$. Her fasting blood sugar was normal $(6.00 \mathrm{mmol} / \mathrm{L})$. USG of Whole Abdomen was normal. CT scan of whole abdomen was found fatty change in liver and small right kidney.

\section{Discussion}

The most studied mechanism of action of colchicine is its capacity to bind to tubulins, thereby blocking the assembly and polymerization of microtubules. Microtubules, the key component of the cytoskeleton, are made up of $\alpha / \beta$-tubulin heterodimers. Microtubules are involved in various cellular processes including maintenance of cell shape, migration and division, intracellular trafficking, cytokine and chemokine secretion and regulation of ion channels. Colchicine is a classical anti-inflammatory drug that blocks mitotic cells in metaphase. It binds to the ends of microtubules to prevent the elongation of the microtubule polymer. At low concentrations, colchicines arrests microtubule growth, and at higher concentrations, colchicines promote microtubule depolymerization ${ }^{6}$.

Glucose-stimulated insulin secretion (GSIS) in pancreatic $\beta$ cells maintains glucose homeostasis and prevents diabetes. For glucose-stimulated insulin secretion (GSIS), insulin granules have to be localized close to the plasma membrane. Microtubules, counterintuitively, restrict granule availability for secretion. In $\beta$ cells, microtubules originate at the Golgi and form a dense non-radial meshwork. Non-directional transport along these microtubules limits granule dwelling at the cell periphery, restricting granule availability for secretion. High glucose destabilizes microtubules, decreasing their density; such local microtubule depolymerization is necessary for GSIS, likely because granule withdrawal from the cell periphery becomes inefficient ${ }^{7}$.

Consistently, microtubule depolymerization by 
Colchicine may block granule withdrawal, increases their concentration at exocytic sites, and dramatically enhances GSIS.

\section{Conclusion}

In this case, this patient may have been diabetic for a long time but was not diagnosed and inflammatory condition of the patient may also regulate catecholamines, steroids and other counter regulatory hormones of insulin which may lead to high blood glucose concentration. So high concentration of glucose already destabilized most of the microtubules before, and when the patient was treated with Colchicine, the furthermore depolymerization of $\beta$ cell microtubules may have stimulated glucose stimulated insulin secretion and caused hypoglycemia. Although very rarely seen, Colchicine is regarded as a putative cause of hypoglycemia and this case was a very rare example. But for safety purpose, colchicine should be administered with strict blood glucose level monitoring.

\section{References}

1. Leung YY, Hui LLY, Kraus VB. Colchicine-Update on mechanisms of action and therapeutic uses. Semin Arthritis Rheum. 2015;45(3):341-50.

2. Konda C, Rao AG. Colchicine in dermatology. Indian J DermatolVenerolLeprol 2010;76:201-5

3. Terkeltaub RA, Furst DE, Bennett K, Kook KA, Crockett RS, Davis MW, et al. High versus low dosing of oral colchicine for early acute gout flare: twentyfour-hour outcome of the first multicenter, randomized, double-blind, placebo-controlled, parallel-group, dose-comparison colchicine study. Arthritis Rheum 2010;62:1060-8.

4. U.S. Food and Drug Administration. [Internet] Available from: $<$ https://www.accessdata.fda.gov/drugsatfda_docs/label/2015/0223 52s022lbl.pdf . Revised 12/2015.

5. Jameson JL, Groot LJD, Kretser DD, Giudice LC, Grossman A, Melmed S, Potts JT, Jr., Weir GC, et al. Endocrinology: adult \& pediatric. 7th ed. China: Elsevier Saunders; 2016. 819p.

6. Bhattacharyya B, Panda D, Gupta S, Banerjee M. Anti-mitotic activity of colchicine and the structural basis for its interaction with tubulin. Med Res Rev 2008;28:155-83.

7. Zhu X, Hu R, Brissova M, Stein RW, Powers AC, Gu G, Kaverina I, et al. Microtubules negatively regulate insulin secretion in pancreatic $\beta$ cells. Dev Cell. 2015; 34(6): 656-668. 